\title{
Antimicrobial resistance of Escherichia coli isolates from cattle in Eastern Algeria
}

\author{
Djanette Barour ${ }^{1,2}$, Amine Berghiche ${ }^{1,2}$ and Nadji Boulebda ${ }^{1,2}$ \\ 1. Department of Veterinary Science, Institute of Agronomic and Veterinarian Sciences, University of Mohamed Cherif \\ Messaâdia, Souk Ahras, Algeria; 2. Laboratory of Science and Technique of the Living, University of Mohamed Cherif \\ Messaâdia, Souk Ahras, Algeria. \\ Corresponding author: Djanette Barour, e-mail: djanette.barour@yahoo.fr \\ Co-authors: AB: amine_berghiche@yahoo.com, NB: nadji.boulebda@laposte.net \\ Received: 23-04-2019, Accepted: 24-06-2019, Published online: 07-08-2019
}

doi: 10.14202/vetworld.2019.1195-1203 How to cite this article: Barour D, Berghiche A, Boulebda N (2019) Antimicrobial resistance of Escherichia coli isolates from cattle in Eastern Algeria, Veterinary World, 12(8): 1195-1203.

\begin{abstract}
Background and Aim: Lack of information about the antibiotic resistance in commensal Escherichia coli from Algerian livestock prompted us to do this study to determine the different levels of antimicrobial susceptibility, antibiotic multidrug resistance (MDR) rates, and phenotypical patterns of E. coli strains isolated from healthy cattle to control the spread of animal-resistant strains to humans and the environment.

Materials and Methods: A total of 198 cattle were sampled (swabbed in the rectum), reared in the farms of Souk Ahras, Tebessa, and Oum el Bouaghi governorates of Eastern Algeria. Isolation of E. coli strains was performed on MacConkey agar and then the different strains were identified to the species level using an API 20E identification kit. Antimicrobial susceptibility was determined using a panel of 13 antibiotic disks by disk diffusion method on Mueller-Hinton agar. The double-disk synergy test with cefotaxime and amoxicillin-clavulanate disks was used for the screening of extended-spectrum beta-lactamase phenotypes. For colistin susceptibility, the minimum inhibitory concentration was examined using broth microdilutions technique.

Results: The results showed that among the $198 \mathrm{E}$. coli isolates, elevated resistance rates were observed for ampicillin $(59.09 \%)$ and tetracycline (43.43\%), and moderate resistance rates for cephalothin $(16.16 \%)$, trimethoprim/sulfamethoxazole $(15.15 \%)$, and amoxicillin/clavulanate (11.62\%); however, low resistance rates were found for nalidixic acid (8.08\%), ciprofloxacin (7.07\%), kanamycin (6.56\%), cefotaxime (4.54\%), chloramphenicol (4.04\%), nitrofurantoin $(2.52 \%)$, cefoxitin $(2.02 \%)$, gentamycin $(1.01 \%)$, and no resistance to colistin. However, nine extended-spectrum $\beta$-lactamases producing E. coli strains were identified. Forty-four different patterns were determined, indicating a wide variety of resistance, ranging from one antimicrobial to a combination of 10. Analysis of coresistances revealed that 63 isolates $(31.82 \%)$ were susceptible to all antibiotics used in the study, 42 isolates $(21.21 \%)$ were resistant to one antibiotic, 43 isolates $(21.72 \%)$ were resistant to two antibiotics, 24 isolates $(12.12 \%)$ resistant to three antibiotics, 26 isolates $(13.13 \%)$ were resistant for more than three agents, and 45 isolates $(22.73 \%$ ) were MDR (which means resistant to three or more families of antibiotics).

Conclusion: This study demonstrates that commensal E. coli remains a potential source of antibiotic resistance in view of the high prevalence of antimicrobial resistance. The vast range of MDR phenotypes, especially extended-spectrum ß-lactamases producing strains, emphasizes the urgent requirement to adopt measures to control the use of antimicrobials, in particular, by private veterinarians, as well as the strengthening of veterinary surveillance networks for antimicrobial resistance to control the spread of MDR bacteria from animals to humans and the environment.
\end{abstract}

Keywords: antimicrobial resistance, cattle, Eastern Algeria, Escherichia coli.

\section{Introduction}

Antimicrobial agents are used therapeutically in animals and humans for control of bacterial infections and may be incorporated into commercial livestock and poultry feed at subtherapeutic doses for growth promotion $[1,2]$. Antibiotics have significantly reduced mortality associated with infectious diseases during the $20^{\text {th }}$ century; unfortunately, their massive and repeated use, in animal farming, has led to the emergence of bacteria multidrug resistance (MDR)

Copyright: Barour, et al. Open Access. This article is distributed under the terms of the Creative Commons Attribution 4.0 International License (http://creativecommons.org/licenses/by/4.0/), which permits unrestricted use, distribution, and reproduction in any medium, provided you give appropriate credit to the original author(s) and the source, provide a link to the Creative Commons license, and indicate if changes were made. The Creative Commons Public Domain Dedication waiver (http://creativecommons.org/ publicdomain/zero/1.0/) applies to the data made available in this article, unless otherwise stated. to these drugs [3]. While antimicrobials are used to target pathogenic organisms, simultaneous selection pressure is exerted on the commensal enterobacteria, encouraging the development and maintenance of antimicrobial resistance in these bacteria [4]. Both antimicrobial-resistant pathogens and commensal organisms can disseminate to humans through direct contact with animals [5] or through the food chain [6,7]. Despite the abundance of phenotypes of antibiotic resistance observed within bacteria, only four mechanisms by which these resistances are acquired have been described, all of which are controlled by the action of specific genes: Enzymatic inactivation or modification of antimicrobial agents, impermeability of the bacteria cell wall or membrane, active expulsion of the drug by the cell efflux pump, and alteration in target receptors $[8,9]$. Thus, the genes coding for the antibacterial resistance determinants are located either on the 
bacterial chromosome, or on mobile genetic elements such as plasmids, transposons, and integrons and can be transmitted vertically and horizontally $[8,10]$.

Commensal Escherichia coli are part of the intestinal flora of human and animals with certain strains being pathogenic and causing conditions including gastroenteritis, cystitis, meningitis, peritonitis, and septicemia. Changes in the antibiotic resistance of this species may serve as an early warning of the development of resistance by related pathogenic bacteria [7,11-13]. Several international studies have been reported on the fecal carriage of resistant $E$. coli in cattle [14-18]; but in Algeria, the majority of published papers are focused only on human pathogenic strains of E. coli [19-22], while some papers have been reported on resistant $E$. coli strains in poultry [23,24], the current information on antimicrobial resistance in commensal $E$. coli strains in cattle is very limited.

Lack of information about the antibiotic resistance in commensal $E$. coli from livestock requires us to deepen research in this area to know the epidemiology of antimicrobial susceptibility of $E$. coli strains and contribute for a better use of antibiotics in Algerian cattle, whose food is intended for human consumption. For these reasons, we carried out this study using the disk diffusion method on MuellerHinton agar, in $E$. coli isolates from healthy cattle during a period of 2 years, to determine their different levels of antimicrobial susceptibility, the rates of MDR, and their different phenotypically patterns of antibiotic resistance.

\section{Materials and Methods}

\section{Ethical approval}

This study did not require any ethical approval from the University Animal Ethics Committee and was performed in accordance with Algerian laws and regulations on animal welfare.

\section{Study area}

This study was carried out in several localities of the governorates of Souk Ahras, Tébessa, and Oum el Bouaghi, all located in the east of Algeria (Figure-1).

\section{Sample collection}

From March 2016 to March 2018, 198 cattle were swabbed in the rectum. Swabs loaded with feces were then dissolved into $2 \mathrm{ml}$ of sterile physiological saline and sent directly to the laboratory.

\section{E. coli isolation and identification}

The samples were inoculated on Mac Conkey agar for $24 \mathrm{~h}$ at $37^{\circ} \mathrm{C}$; positive lactose colonies were tested by Gram stain and oxidase testing. The isolates were then identified to the species level using an API 20E identification kit (bioMérieux, France).

\section{Antimicrobial susceptibility testing}

Antibiotic sensitivity was determined using disk diffusion method on Mueller-Hinton agar (Merck), following Clinical and Laboratory Standards Institute (CLSI) standards [25]. The double-disk synergy test with cefotaxime and amoxicillin-clavulanate disks was used for the screening of extended-spectrum ß-lactamases (ESBL)phenotype. E. coli ATCC 25922 and Klebsiella pneumoniae ATCC 700603 were used

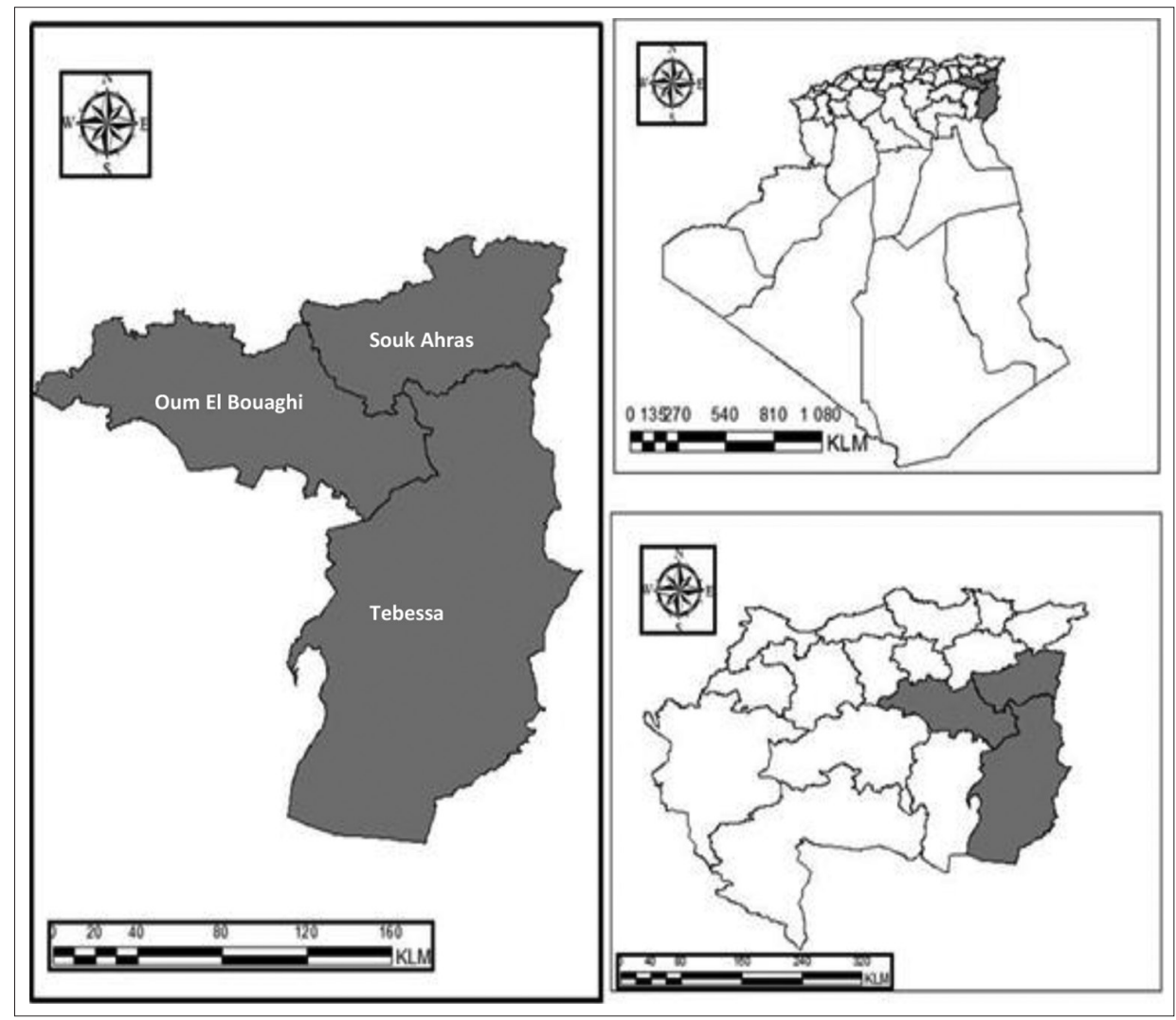

Figure-1: Map of Algeria showing the sampling sites of the study (The map was generated in "ESRI ${ }^{\circ}$ ArcGIS 9.1 for desktop" software). 
as ESBL negative and positive reference strains, respectively.

The antibiotics tested (Oxoid) their concentrations and the breakpoints are shown in Table-1 $[25,26]$. Only for colistin susceptibility, the minimum inhibitory concentration (MIC) was examined using broth microdilutions technique (Table-1) [25,26]. The MIC for each isolate was read as the lowest dilution demonstrating no visible growth, based on CLSI [26].

\section{Statistical analysis}

- Descriptive analysis: The graphic representation was performed using the program (Microsoft Office Excel, 2007).

- Data analysis: To compare coresistances in different isolates, the Kruskal-Wallis test was used. This test was a non-parametric statistical test that assesses the differences among three or more independently sampled groups on a single, non-normally distributed continuous variable [27].

- Cluster analysis: We used the free software (Past 3.22 ), to determine the coefficient of correlation between the number of resistances and the number of strains for each of the antibiogram profiles detected, using algorithm paired group and similarity measure using Euclidean distance. The correlation coefficient was equal to 0.07798 (Figure-2).

\section{Results and Discussion}

This study aimed to determine the resistance rates of commensal $E$. coli strains to a panel of 13 antibiotics belonging to nine different families, as well as to determine the rates of MDR and the different phenotypical patterns of antibiotic resistance. Among the 198 fecal samples, 198 E. coli strains were isolated, which represents $100 \%$ isolation rate; this percentage is in accordance with Bywater et al. [28].

Table-1: Disk drug concentrations and diffusion zone breakpoints for antimicrobial sensitivity and the minimal inhibitory concentration only for colistin sensitivity $[25,26]$.

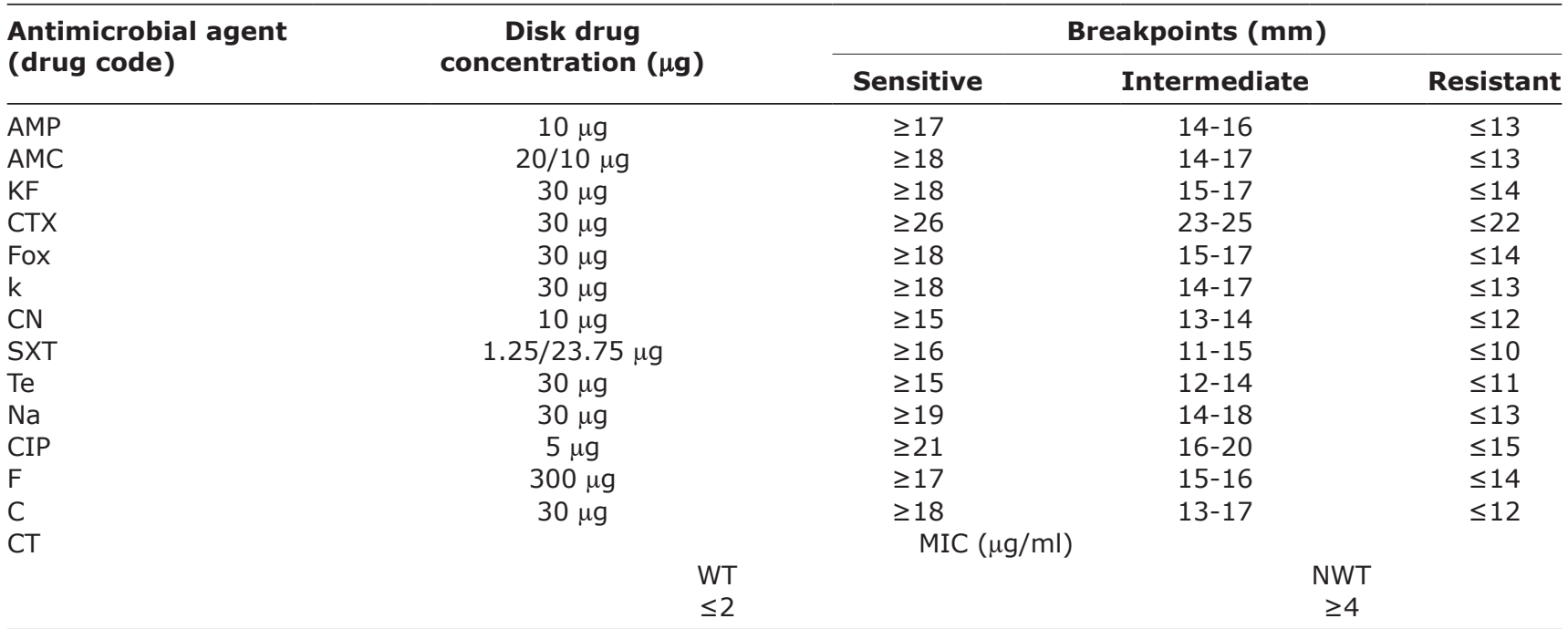

WT=Wild type, NWT=Non-wild type, MIC=Minimum inhibitory concentration , AMP=Ampicillin, AMC=Amoxicillin/clavulanate, $\mathrm{KF}=$ Cephalothin, $\mathrm{CTX}=$ Cefotaxime, Fox=Cefoxitin, $\mathrm{k}=$ Kanamycin, $\mathrm{CN}=$ Gentamycin, $\mathrm{SXT}=$ Trimethoprim/sulfamethoxazole, $\mathrm{Te}=$ Tetracyclines, $\mathrm{Na}=$ Nalidixic acid, $\mathrm{CIP}=$ Ciprofloxacin, $\mathrm{F}=$ Nitrofurantoin, $\mathrm{C}=$ Chloramphenicol, $\mathrm{CT}=$ Colistin

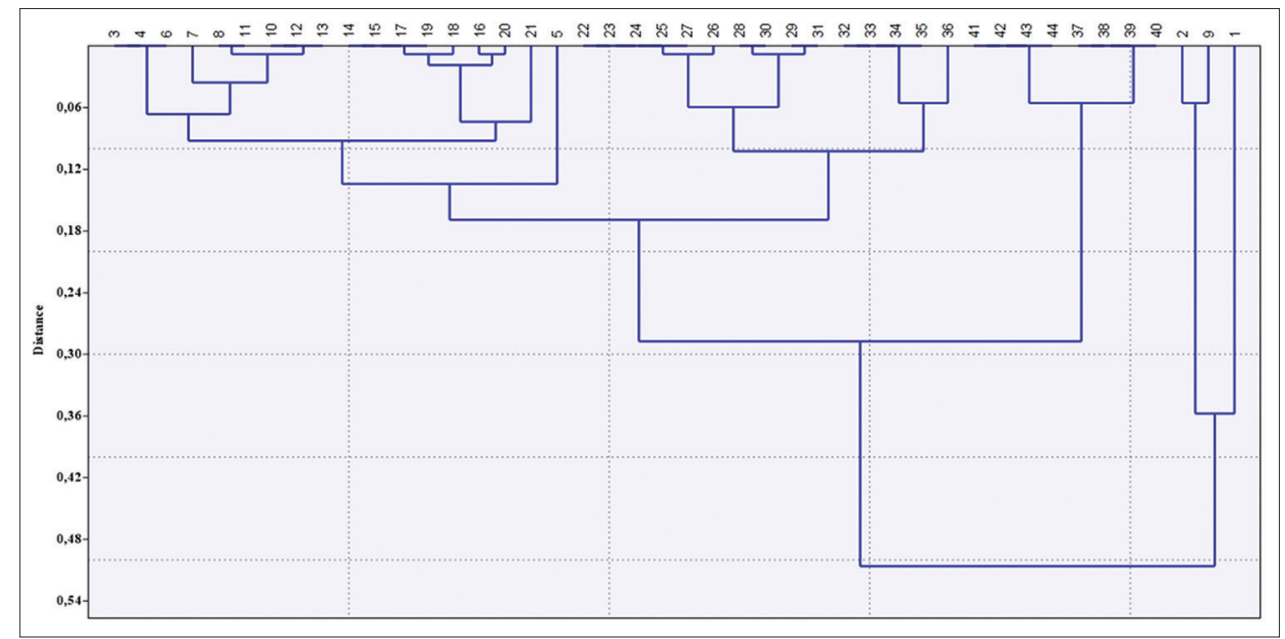

Figure-2: Patterns of antimicrobial resistance phenotypes for $E$. coli strains isolated in the study. The upper margin indicates the antibiogram patterns of phenotypic antimicrobial resistance detected from 1 to 44 . The left margin indicates the distance between the different clusters. 


\section{Antibiotic resistance rates}

The resistance rates (Table-2) of the 198 isolated $E$. coli show high rates of resistance for ampicillin (AMP) $(59.09 \%)$ and tetracycline (TE) (43.43\%), moderate rates of resistance were observed for cephalothin (16.16\%), trimethoprim/sulfamethoxazole (SXT) (15.15\%), and amoxicillin/clavulanate (11.62\%); however, the low resistance rates have been observed for nalidixic acid (8.08\%), ciprofloxacin $(7.07 \%)$, kanamycin $(6.56 \%)$, cefotaxime $(4.54 \%)$, chloramphenicol $(4.04 \%)$, nitrofurantoin $(2.52 \%)$, cefoxitin $(2.02 \%)$, gentamycin $(1.01 \%)$, and no resistance was recorded for colistin $(0 \%)$. However, nine extended-spectrum beta-lactamases producing E. coli were detected.

Beta-lactams are the most commonly used antibiotics (Figure-3) for the treatment of infections caused by Enterobacteriaceae. Resistance to beta-lactam antibiotics develops as a result of mutations or the acquisition of genetic material such as plasmids, transposons, or integrons from other resistant bacteria [29]. In Eastern Algeria, this class of antibiotics is widely used $[2,30]$. Their extensive and long-term use render their resistance rate high as a function of selection pressure, this resistance in $E$. coli is mostly ensured by $ß$-lactamases, which presently contains more than 200 enzymes that hydrolyze the B-lactam cycle and inactivate it in a manner that represents a very high risk to public health $[31,32]$.

Among B-lactam antibiotics, AMP is one of the oldest drugs used in bovines; it is indicated for the treatment of septicemia, digestive, respiratory, and genitourinary infections [33]; this antimicrobial has the highest resistance rate with $59.09 \%$, the finding is compatible with that of Sawant et al. [34], But higher than other findings of previous studies $[17,35,36]$ and the resistance rate of the combination amoxicillin and clavulanate is lower with $11.62 \%$.

Tetracycline is a wide-spectrum bacteriostatic antibiotic indicated in cattle for the treatment of septicemia, respiratory, digestive, genitourinary, and interdigital infections; resistance to this antibiotic in E. coli is increasing [33,37], this resistance to tetracycline is mediated by plasmid, with a high variability of genetic determinants [38]. A large number of genetic determinants of tetracycline resistance allows sensitive bacteria to acquire resistance factors [39]. We reported a high resistance rate to tetracycline with $43.43 \%$, which may be explained by its extensive use by clinical veterinarians in Algeria [30,40], this result is similar to the finding of Abbassi et al. [14] Other researchers have found lower rates of resistance to this

Table-2: Frequencies of antibiotics resistance in E. coli isolates.

\begin{tabular}{|c|c|c|c|}
\hline \multirow[t]{2}{*}{ Families of antibiotics } & \multirow[t]{2}{*}{ Antibiotics } & \multirow{2}{*}{$\frac{\text { Sensitive isolates }}{\mathrm{n}(\%)}$} & \multirow{2}{*}{$\frac{\text { Resistant isolates }}{\mathrm{n}(\%)}$} \\
\hline & & & \\
\hline \multirow[t]{2}{*}{ Beta-lactams } & AMP & $81(40.91)$ & $117(59.09)$ \\
\hline & AMC & $175(88.38)$ & $23(11.62)$ \\
\hline \multirow{3}{*}{ Cephalosporin } & $\mathrm{KF}$ & $166(83.84)$ & $32(16.16)$ \\
\hline & CTX & $189(95.45)$ & $9(4.54)$ \\
\hline & FOX & $194(97.98)$ & $4(2.02)$ \\
\hline \multirow[t]{2}{*}{ Aminoglycosides } & $\mathrm{K}$ & $185(93.43)$ & $13(6.56)$ \\
\hline & $\mathrm{CN}$ & $196(98.99)$ & $2(1.01)$ \\
\hline Sulfonamides & SXT & $168(84.85)$ & $30(15.15)$ \\
\hline Cyclins & $\mathrm{Te}$ & $112(56.56)$ & $86(43.43)$ \\
\hline \multirow[t]{2}{*}{ Quinolones } & NA & $182(91.92)$ & $16(8.08)$ \\
\hline & CIP & $184(92.93)$ & $14(7.07)$ \\
\hline Polymyxins & $\mathrm{CT}$ & $198(100)$ & $0(0)$ \\
\hline Nitrofurans & $\mathrm{F}$ & $193(97.47)$ & $5(2.52)$ \\
\hline Phenicols & $\mathrm{C}$ & $190(95.96)$ & $8(4.04)$ \\
\hline
\end{tabular}

$\mathrm{AMP}=$ Ampicillin, $\mathrm{AMC}=$ Amoxicillin +clavulanate, $\mathrm{KF}=$ Cephalothin, $\mathrm{CTX}=$ Cefotaxime, $\mathrm{FOX}=$ Cefoxitin, $\mathrm{K}=$ Kanamycin, $\mathrm{CN}=$ Gentamycin, SXT=Trimethoprim/sulfamethoxazole, Te=Tetracycline, NA=Nalidixic acid, CIP=Ciprofloxacin, $\mathrm{CT}=$ Colistin, $\mathrm{F}=$ Nitrofurantoin, $\mathrm{C}=$ Chloramphenicol

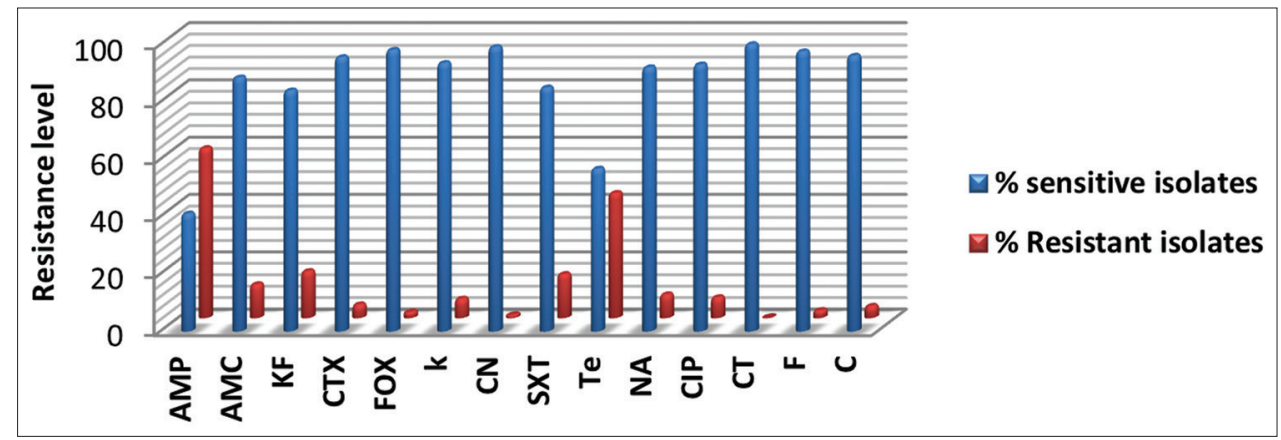

Figure-3: Frequencies of antibiotics resistance in Escherichia coli isolates. 
molecule [17,39] as well as higher rates such as those obtained by Sawant et al. [34]; the high levels can be interpreted by the mechanisms of tetracycline resistance which are very ancient [41] and that tetracycline is a naturally occurring compound which bacteria can be exposed to in the outside in their use as human therapy, as prophylactics or as growth promoters in livestock [38].

Resistance to the many molecules of the cephalosporin family is often a result of stable mutations [38], a plasmid-mediated acquired resistance to the third-generation cephalosporins is now also reported by Payne and Amyes [42]. Bacteria can easily retain these stable mutations which confer resistance to cephalosporins, even in the absence of selective pressure to maintain resistance [39].

In our study, the first-generation cephalosporins are represented by cephalothin, for which a moderate resistance rate is observed $16.16 \%$, which is in agreement with the results of Sayah et al. [39] The prevalence of resistance to the second- and third-generation cephalosporins, predominantly cefoxitin and cefotaxime, is low in our study with $2.02 \%$ and $4.54 \%$, respectively, although nine E. coli strains ESBL producing were identified using a double-disk synergy test with cefotaxime and amoxicillin-clavulanate disks, other studies have reported the absence of cefotaxime resistance $[14,28,35,43]$ and a similar resistance rate to our result for the third-generation cephalosporins is found [44].

In Algeria, several studies have been performed on the characterization of extended-spectrum $B$-lactamases on many hosts, in humans by Touati et al. and Iabadene et al. [21,45], in poultry by Belmahdi et al. [23] and Meguenni et al. [24], and in pets (dogs and cats) by Yousfi et al. [46], but there are not any studies that investigate the topic of ESBL in commensal $E$. coli in cattle.

For trimethoprim/sulfamethoxazole, a moderate resistance rate is observed (15.15\%); this agrees with Li et al. [44]. In combination of the two molecules: Trimethoprim/sulfamethoxazole is synergistic and produces a wide-spectrum bactericidal effect [33], the use of this antibiotic in animal feed, like its uncontrolled use in human medicine, can contribute for a long time to the development and transmission of genes encoding this marker of resistance [47]; sulfonamide resistance is widely prevalent and cross-resistance between sulfonamides is complete [38], so caution in the use of these antibiotics is required.

In Algeria, many antibiotics have been banned by ministerial decision since 2006 , such as gentamycin, ciprofloxacin, chloramphenicol, and nitrofurantoin, despite these prohibition resistance levels have been recorded for these molecules with $1.1 \%, 7.07 \%$, $4.04 \%$, and $2.52 \%$, respectively, and the National Network for the Surveillance of the Resistance of Bacteria to Antibiotics is still recording significant levels of resistance to chloramphenicol $(23.5 \%)$ and furans $(18.3 \%)$ for $E$. coli strains, despite their prohibition since December 24, 2006 [48].

Other researchers from other countries have also reported chloramphenicol resistance in $E$. coli isolates from chickens and pigs in the absence of phenicol use for many years $[49,50]$. Coresistance of chloramphenicol with other unrelated compounds seems to be the probable explanation, as coresistance caused by the use of sulfonamides and streptomycin due to gene linkage has been reported [50-53].

Weak resistance rates are observed for nalidixic acid with $8.08 \%$ and ciprofloxacin with $7.07 \%$, noting that ciprofloxacin is prohibited, which may be explained by the fact that fluoroquinolone resistance is linked to a chromosome mutation and the development of resistance to one agent causes cross-resistance to other fluoroquinolones [39].

Bywater et al. have abnormally reported a relatively high incidence of ciprofloxacin resistance in Campylobacter spp., despite the prohibition of its use, such observations as for chloramphenicol, explains at least some differences between antibiotic resistance and veterinary use of certain classes of antibiotics.

Kanamycin is a relatively old molecule, but its resistance rate is low $6.56 \%$, explained by the low use of its family (aminoglycosides) by Algerian veterinary practitioners [30]. For gentamycin, we found a low resistance rate with $1.01 \%$; this resistance explained by its illegal use because it is prohibited for use in Algeria.

Colistin is the only antibiotic that has not presented resistance $(0 \%)$, which is in agreement with the results of de Jong et al. [35], who conducted this study in five European countries. Colistin is widely used for the treatment of colibacillary infections in animals but in human medicine has been excluded from therapeutic protocols due to its particular renal toxicity and became an antibiotic prescribed only for the treatment of serious human infections caused by bacteria resistant to any other antibiotics [54]. Colistin is also one of the most critical antibiotics, which the WHO has recently recommended to reduce in food-producing animals [55]

\section{Coresistances and MDR rate}

Analysis of coresistance for the $198 \mathrm{E}$. coli isolates (Table-3) showed that 63 isolates $(31.82 \%)$ were sensitive to all antibiotics used in the study, 42 isolates $(21.21 \%)$ were resistant to one antibiotic, 43 isolates $(21.72 \%)$ to two antibiotics, 24 isolates $(12.12 \%)$ to three antibiotics, and 26 isolates (13.13\%) for more than three antibiotics. Based on Kruskal-Wallis test results (non-parametric test), it can be estimated that there is a significant difference between the different coresistance rates with $\mathrm{p}=0.09023$, thus showing a wide variety of phenotypes (Table-4).

On the other side, 45 isolates $(22.73 \%)$ were MDR, which means resistant to three or more families of antibiotics since we considered beta-lactams and cephalosporins as two different families. 
Table-3: Coresistances of the $198 \mathrm{E}$. coli isolates from cattle.

\begin{tabular}{|c|c|c|c|c|c|c|}
\hline \multirow{3}{*}{$\begin{array}{l}\text { Number of } \\
E . \text { coli isolates }\end{array}$} & \multicolumn{5}{|c|}{ Number $(n)$ and percentages $(\%)$ of isolates resistant to } & \multirow{3}{*}{$\frac{\text { Kruskal-Wallis } \chi^{2}}{\text { p-value }}$} \\
\hline & No agent & One agent & Two agents & Three agents & More than three agents & \\
\hline & n (\%) & n (\%) & n (\%) & n (\%) & n (\%) & \\
\hline 198 & $63(31.82)$ & $42(21.21)$ & $43(21.72)$ & $24(12.12)$ & $26(13.13)$ & 0.09023 \\
\hline
\end{tabular}

E. coli=Escherichia coli

MDR bacteria present an impending risk to human and animal health, considering the limitations that they impose on the selection of antibiotic therapy for infections as well as the dangers of therapeutic failure. The MDR reported in our study can be the result of an independent resistance for each antibiotic or a coresistance.

A few major factors can contribute to increase bacterial MDR: The transfer of resistance determinants by movable genetic elements including plasmids, transposons, and gene cassettes into integrons and by changing regulation in mar locus [56].

Due to the indiskriminate exploitation of antimicrobial agents, high incidence of MDR may apparently occur, which may ultimately replace drug-sensitive microorganisms in the saturated antibiotic environment [7]. The MDR rate we have recorded is higher than that recorded by other authors $[36,39,43]$, which motivates the monitoring of MDR E. coli strains.

\section{Variety of antimicrobial resistance phenotypes}

Depending to their antibiotic resistance phenotypes, the 198 isolates of $E$. coli belong to 44 different phenotypes (Figure-2), thus showing a large variety of resistances, ranging from one antimicrobial to a combination of 10 (Table-5).

The two most frequent phenotypes with the same rate are AMP and AMP-TE with 14.65\%, followed by the combination AMP-SXT-TE with 5.55\% and TE with $5.05 \%$. All MDR phenotypes are AMP resistant with a lower resistance level to tetracycline, which suggests that $E$. coli strains resistant to these antibiotics have an increased ability to be resistant for other antimicrobials, it has been reported in several previous studies that the most common phenotypes included a sole resistance to tetracycline or in association with other antibiotics $[17,39,43]$.

There were nine different phenotypes detected with a rate of $4.54 \%$ producing extended-spectrum B-lactamases and all are MDR ranging from five antimicrobials to a combination of 10. ESBL phenotype includes resistance to penicillins and cephalosporins, with the exception of cephamycins, which is the cause of many therapeutic failures [29], which requires the surveillance of strains with this type of phenotype.

The propagation of enterobacterial strains producing ESBL is a complex phenomenon involving three mechanisms. The first is clonal dissemination, where a strain producing ESBL can spread through horizontal contact between individuals. The second type is the transmission of one or several plasmids to
Table-4: Kruskal-Wallis test.

\begin{tabular}{lcc}
\hline & A & B \\
\hline A & 1 & 0.01219 \\
B & 0.01219 & 1 \\
\hline \multicolumn{2}{c}{ Mann-Whitney pair wise comparison } \\
H $($ K2 $)=6.818$ & \\
Hc (tie-corrected $)=6.818$ &
\end{tabular}

another bacterial strain of the same or different species. The third is the transfer of resistance elements present in transposons or integrons between different plasmids. Plasmids often have other resistance genes (including aminoglycosides, tetracyclines, sulfonamides, and trimethoprim), hence, the notion of coresistance, coexpression, and coselection [57].

In this study, the high variability of resistance phenotypes can be explained by coresistance (acquisition of resistance to several antibiotics of different classes), as the plasmids exchanged usually have several resistance genes such as the coresistance of $E$. coli to cephalosporins, penicillins, chloramphenicol, tetracyclines, and fluoroquinolones.

In the same way as for cross-selection, the use of an antibiotic to which the bacterium resists will allow the coselection of all the resistances supported by the same plasmid. The diffusion and acquisition of resistances are independent of the use of antibiotics, but their use, without being aware of the state of bacterial sensitivity, can quickly cause the selection of MDR strains [58].

- The upper margin indicates the antibiogram patterns of phenotypic antimicrobial resistance detected from 1 to 44

- The left margin indicates the distance between the different clusters.

\section{Conclusion}

Antibiotic sensitivity of 198 isolates of E. coli collected from cattle in Eastern Algeria showed high frequencies of resistance to AMP and TE and a high level of E. coli producing ESBLs was detected. ESBL strains are the cause of many therapeutic failures, which require the surveillance of strains that contain this phenotype. The coresistance analysis showed a high rate of MDR strains, 44 different phenotypes were also detected, showing a high variety of resistance, ranging from 1 to 10 antimicrobials combination.

The high rate of antimicrobial resistance in commensal E. coli from Algerian livestock emphasizes the urgency of intervention to implement the measures to control the use of antimicrobials, in particular, by 
Table-5: Patterns of antimicrobial resistance phenotypes for Escherichia coli strains isolated in the study, with antibiogram pattern codes.

\begin{tabular}{|c|c|c|c|}
\hline Number of resistances & Antibiogram patterns & Code of patterns & Number of strains \\
\hline 0 & Susceptible to all antimicrobials & 1 & 63 \\
\hline \multirow[t]{5}{*}{1} & AMP & 2 & 29 \\
\hline & $\mathrm{KF}$ & 3 & 1 \\
\hline & FOX & 4 & 1 \\
\hline & TE & 5 & 10 \\
\hline & CIP & 6 & 1 \\
\hline \multirow[t]{7}{*}{2} & $\mathrm{AMP}+\mathrm{KF}$ & 7 & 6 \\
\hline & $\mathrm{AMP}+\mathrm{AMC}$ & 8 & 1 \\
\hline & $\mathrm{AMP}+\mathrm{TE}$ & 9 & 29 \\
\hline & $A M P+N A$ & 10 & 2 \\
\hline & $\mathrm{K}+\mathrm{TE}$ & 11 & 1 \\
\hline & $\mathrm{TE}+\mathrm{S} X \mathrm{~T}$ & 12 & 2 \\
\hline & $\mathrm{TE}+\mathrm{CIP}$ & 13 & 2 \\
\hline \multirow[t]{8}{*}{3} & $A M P+K F+A M C$ & 14 & 1 \\
\hline & $\mathrm{AMP}+\mathrm{KF}+\mathrm{SXT}$ & 15 & 1 \\
\hline & $\mathrm{AMP}+\mathrm{KF}+\mathrm{TE}$ & 16 & 4 \\
\hline & $\mathrm{AMP}+\mathrm{KF}+\mathrm{F}$ & 17 & 1 \\
\hline & $A M P+A M C+S X T$ & 18 & 2 \\
\hline & $\mathrm{AMP}+\mathrm{AMC}+\mathrm{TE}$ & 19 & 1 \\
\hline & $\mathrm{AMP}+\mathrm{K}+\mathrm{TE}$ & 20 & 3 \\
\hline & $\mathrm{AMP}+\mathrm{SXT}+\mathrm{TE}$ & 21 & 11 \\
\hline \multirow[t]{6}{*}{4} & $A M P+K F+A M C+F O X$ & 22 & 1 \\
\hline & $\mathrm{AMP}+\mathrm{KF}+\mathrm{AMC}+\mathrm{SXT}$ & 23 & 1 \\
\hline & $\mathrm{AMP}+\mathrm{KF}+\mathrm{AMC}+\mathrm{F}$ & 24 & 1 \\
\hline & $\mathrm{AMP}+\mathrm{AMC}+\mathrm{TE}+\mathrm{C}$ & 25 & 1 \\
\hline & $\mathrm{AMP}+\mathrm{K}+\mathrm{SXT}+\mathrm{TE}$ & 26 & 2 \\
\hline & $\mathrm{AMP}+\mathrm{K}+\mathrm{TE}+\mathrm{NA}$ & 27 & 1 \\
\hline \multirow[t]{4}{*}{5} & $\mathrm{AMP}+\mathrm{KF}+\mathrm{AMC}+\mathrm{TE}+\mathrm{CIP}$ & 28 & 1 \\
\hline & $\mathrm{AMP}+\mathrm{KF}+\mathrm{AMC}+\mathrm{TE}+\mathrm{C}$ & 29 & 2 \\
\hline & $\mathrm{AMP}+\mathrm{KF}+\mathrm{CTX}+\mathrm{TE}+\mathrm{NA}$ & 30 & 1 \\
\hline & $\mathrm{AMP}+\mathrm{SXT}+\mathrm{TE}+\mathrm{NA}+\mathrm{CIP}$ & 31 & 2 \\
\hline \multirow[t]{4}{*}{6} & $\mathrm{AMP}+\mathrm{KF}+\mathrm{AMC}+\mathrm{FOX}+\mathrm{SXT}+\mathrm{TE}$ & 32 & 1 \\
\hline & $\mathrm{AMP}+\mathrm{KF}+\mathrm{AMC}+\mathrm{CTX}+\mathrm{TE}+\mathrm{NA}$ & 33 & 1 \\
\hline & $\mathrm{AMP}+\mathrm{KF}+\mathrm{AMC}+\mathrm{TE}+\mathrm{CIP}+\mathrm{C}$ & 34 & 1 \\
\hline & $A M P+A M C+K+S X T+T E+C$ & 35 & 1 \\
\hline 7 & $\mathrm{AMP}+\mathrm{KF}+\mathrm{AMC}+\mathrm{CTX}+\mathrm{TE}+\mathrm{NA}+\mathrm{CIP}$ & 36 & 1 \\
\hline \multirow[t]{4}{*}{8} & $\mathrm{AMP}+\mathrm{KF}+\mathrm{AMC}+\mathrm{CTX}+\mathrm{SXT}+\mathrm{TE}+\mathrm{NA}+\mathrm{CIP}$ & 37 & 1 \\
\hline & $A M P+K F+A M C+C T X+T E+N A+C I P+F$ & 38 & 1 \\
\hline & $\mathrm{AMP}+\mathrm{KF}+\mathrm{CTX}+\mathrm{K}+\mathrm{SXT}+\mathrm{TE}+\mathrm{NA}+\mathrm{CIP}$ & 39 & 1 \\
\hline & $\mathrm{AMP}+\mathrm{KF}+\mathrm{CTX}+\mathrm{K}+\mathrm{SXT}+\mathrm{TE}+\mathrm{NA}+\mathrm{F}$ & 40 & 1 \\
\hline \multirow[t]{2}{*}{9} & $\mathrm{AMP}+\mathrm{KF}+\mathrm{AMC}+\mathrm{FOX}+\mathrm{SXT}+\mathrm{TE}+\mathrm{NA}+\mathrm{CIP}+\mathrm{F}$ & 41 & 1 \\
\hline & $\mathrm{AMP}+\mathrm{AMC}+\mathrm{K}+\mathrm{CN}+\mathrm{SXT}+\mathrm{TE}+\mathrm{NA}+\mathrm{CIP}+\mathrm{C}$ & 42 & 1 \\
\hline \multirow[t]{2}{*}{10} & $\mathrm{AMP}+\mathrm{KF}+\mathrm{AMC}+\mathrm{CTX}+\mathrm{K}+\mathrm{CN}+\mathrm{SXT}+\mathrm{TE}+\mathrm{NA}+\mathrm{C}$ & 43 & 1 \\
\hline & $\mathrm{AMP}+\mathrm{KF}+\mathrm{AMC}+\mathrm{CTX}+\mathrm{K}+\mathrm{SXT}+\mathrm{TE}+\mathrm{NA}++\mathrm{CIP}+\mathrm{C}$ & 44 & 1 \\
\hline
\end{tabular}

$\mathrm{AMP}=$ Ampicillin, $\mathrm{KF}=$ Cephalothin, $\mathrm{FOX}=$ Cefoxitin, $\mathrm{TE}=$ Tetracycline, $\mathrm{CIP}=$ Ciprofloxacin, $\mathrm{AMC}=$ Amoxicillin+clavulanate, $\mathrm{NA}=$ Nalidixic acid, $\mathrm{K}=$ Kanamycin, SXT=Trimethoprim/sulfamethoxazole, $\mathrm{F}=$ Nitrofurantoin, CTX=Cefotaxime, $\mathrm{C}=$ Chloramphenicol, $\mathrm{CN}=$ Gentamycin

private veterinarians, and to strengthen networks to control bacterial resistance to antibiotics, which can spread to humans and the environment.

\section{Authors' Contributions}

DB collected the samples and provided the bacteriological analyzes. $\mathrm{AB}$ contributed by statistical analyses and the creation of the map; DB and $\mathrm{AB}$ prepared the manuscript; and NB supervised the manuscript. All authors read and approved the final manuscript.

\section{Acknowledgments}

The authors are thankful to the Veterinary Department of the Institute of Agronomic and
Veterinarian Sciences and the Laboratory of Science and Technique of the Living of Mohamed Cherif Messaâdia University, Souk Ahras, Algeria, for providing all the facilities to carry out the present study. The authors did not receive any fund for this study.

\section{Competing Interests}

The authors declare that they have no competing interests.

\section{Publisher's Note}

Veterinary World remains neutral with regard to jurisdictional claims in published map and institutional affiliation. 


\section{References}

1. van den Bogaard, A.E., London, N., Driessen, C. and Stobberingh, E.E. (2001) Antibiotic resistance of fecal Escherichia coli in poultry, poultry farmers and poultry slaughterers. J. Antimicrob. Chemother., 47(6): 763-771.

2. Berghiche, A., Khenenou, T., Kouzi, A. and Labiad, I. (2018) An investigation on the predominant diseases, its diagnosis, and commonly used drugs in the poultry farms in the North-Eastern regions of Algeria. Vet. World, 11(7): 986-989.

3. Berghiche, A. (2019) Special attention is needed for reduce antibiotic residue risk in the white meat produced in Algeria. J. Food Qual. Hazard. Control, 6(2): 44.

4. Barbosa, T.M. and Levy, S.B. (2000) The impact of antibiotic use on resistance development and persistence. Drug Resist. Updat., 3(5): 303-311.

5. Price, L.B., Graham, J.P., Lackey, L.G., Roess, A., Vailes, R. and Silbergeld, E. (2007) Elevated risk of carrying gentamicin-resistant Escherichia coli among U.S. poultry workers. Environ. Health Perspect., 115(12): 1738-1742.

6. Silbergeld, E.K., Graham, J. and Price, L.B. (2008) Industrial food animal production, antimicrobial resistance, and human health. Annu. Rev. Public Health, 29(1): 151-169.

7. van den Bogaard, A.E. and Stobberingh, E.E. (2000) Epidemiology of resistance to antibiotics. Links between animals and humans. Int. J. Antimicrob. Agents, 14(4): 327-335.

8. Harbottle, H., Thakur, S., Zhao, S. and White, D.G. (2006) Genetics of antimicrobial resistance. Anim. Biotechnol., 17(2): 111-124.

9. Hariharan, H. (2007) Antimicrobial therapy in veterinary medicine. $4^{\text {th }}$ ed. Can. Vet. J., 48(7): 744.

10. Rubens, C.E., McNeill, W.F. and Farrar, W.E. (1979) Evolution of multiple-antibiotic-resistance plasmids mediated by transposable plasmid deoxyribonucleic acid sequences. J. Bacteriol., 140(7): 713-719.

11. Aarestrup, F.M., Wegener, H.C. and Collignon, P. (2008) Resistance in bacteria of the food chain: Epidemiology and control strategies. Expert Rev. Anti. Infect. Ther., 6(5): 733-750.

12. Heymann, D.L. (2014) Control of Communicable Diseases Manual. $20^{\text {th }}$ ed. Jones and Bartlett Publishers, Washington, DC. p729.

13. Kahn, C.N., Line, S. and Aiello, S. (2010) The Merck Veterinary Manual. $10^{\text {th }}$ ed. Merck and Co Inc., Whitehouse Station, New Jersey. p1351.

14. Abbassi, M.S., Kilani, H., Zouari, M., Mansouri, R., El Fekih, O., Hammami, S. and Ben Chehida, N. (2017) Antimicrobial resistance in Escherichia coli isolates from healthy poultry, bovine and ovine in Tunisia: A real animal and human health threat. J. Clin. Microbiol. Biochem. Technol., 3(2): 19-23.

15. Brennan, E., Martins, M., McCusker, M.P., Wang, J., Alves, B.M., Hurley, D., El Garch, F., Woehrlé, F., Miossec, C., McGrath, L., Srikumar, S., Wall, P. and Fanning, S. (2016) Multidrug-resistant Escherichia coli in bovine animals Europe. Emerg. Infect. Dis., 22(9): 1650-1652.

16. Haenni, M., Châtre, P., Métayer, V., Bour, M., Signol, E., Madec, J.Y. and Gay, E. (2014) Comparative prevalence and characterization of ESBL-producing Enterobacteriaceae in dominant versus subdominant enteric flora in veal calves at slaughterhouse, France. Vet. Microbiol., 171(3-4): 321-327.

17. Mainda, G., Bessell, P.R., Bessell, P.B., Muma, J.B., McAteer, S.P., Chase-Topping, M.E., Gibbons, J., Stevens, M.P., Gally, D.L. and deC Bronsvoort, B.M. (2015) Prevalence and patterns of antimicrobial resistance among Escherichia coli isolated from Zambian dairy cattle across different production systems. Sci. Rep., 5(1): 12439.

18. Wittum, T.E., Mollenkopf, D.F., Daniels, J.B., Parkinson, A.E., Mathews, J.L., Fry, P.R., Abley, M.J. and
Gebreyes, W.A. (2010) CTX-M-type extended-spectrum $\beta$-lactamases present in Escherichia coli from the feces of cattle in Ohio, United States. Foodborne Pathog. Dis., 7(12): 1575-1579.

19. Messai, Y., Benhassine, T., Naim, M., Paul, G. and Bakour, R. (2006) Prevalence of beta-lactams resistance among Escherichia coli clinical isolates from a hospital in Algiers. Rev. Esp. Quimioter., 19(2): 144-151.

20. Ramdani-Bouguessa, N., Mendonça, N., Leitão, J., Ferreira, E., Tazir, M. and Caniça, M. (2006) CTX-M-3 and CTX-M-15 extended-spectrum $\beta$-lactamases in isolates of Escherichia coli from a hospital in Algiers, Algeria. J. Clin. Microbiol., 44(12): 4584-4586.

21. Touati, A., Benallaoua, S., Forte, D., Madoux, J., Brasme, L. and de Champs, C. (2006) First report of CTX-M-15 and CTX-M-3 beta-lactamases among clinical isolates of Enterobacteriaceae in Béjaia, Algeria. Int. J. Antimicrob. Agents, 27(5): 397-402.

22. Tani, Z.B.A., Decré, D., Genel, N., Zahia, B., Arlet, G. and Drissi, M. (2013) Molecular and epidemiological characterization of enterobacterial multidrug-resistant strains in Tlemcen hospital (Algeria) (2008-2010). Microb. Drug Resist., 19(3): 185.

23. Belmahdi, M., Bakour, S., Al Bayssari, C., Touati, A. and Rolain, J.M. (2016) Molecular characterization of extended-spectrum $\beta$-lactamase- and plasmid AmpC-producing Escherichia coli strains isolated from broilers in Béjaïa, Algeria. J. Glob. Antimicrob. Resist., 6(3): 108-112.

24. Meguenni, N., Le Devendec, L., Jouy, E., Le Corvec, M., Bounar-Kechih, S., Bakour, R. and Kempf, I. (2014) First description of an extended-spectrum cephalosporin-and fluoroquinolone-resistant avian pathogenic Escherichia coli clone in Algeria. Avian Dis., 59(1): 20-23.

25. CLSI (Clinical Laboratory Standards Institute). (2015) Performance Standards for Antimicrobial Susceptibility Testing. Twenty Fifth Information Supplement. M100-S25. National Committee for Clinical Laboratory Standards, Wayne PA.

26. CLSI (Clinical Laboratory Standards Institute). (2017) Performance Standards for Antimicrobial Susceptibility Testing. Twenty-Seventh Information Supplement. M100-S27. National Committee for Clinical Laboratory Standards, Wayne PA.

27. Kruskal, W.H. and Wallis, W.A. (1952) Use of ranks in one-criterion variance analysis. J. Am. Stat. Assoc., 47(260): 583-621.

28. Bywater, R., Deluyker, H., Deroover, E., de Jong, A., Marion, H., McConville, M., Rowan, T., Shryock, T., Shuster, D., Thomas, V., Vallé, M. and Walters, J. (2004) A European survey of antimicrobial susceptibility among zoonotic and commensal bacteria isolated from food-producing animals. J. Antimicrob. Chemother., 54(4): 744-754.

29. Courvalain, P. and Leclerq, R. (2012) Antibiogramme. $3^{\text {rd }}$ ed. ESKA, Paris, France. p800.

30. Mammeri, A. (2018) Antibiotic therapy practices of dairy cows and eventual impact on foodstuffs quality in the governorate of Biskra, Algeria. Res. J. Pharm. Biol. Chem. Sci., 9(6): 1472-1481.

31. Livermore, D.M. (1995) Beta-Lactamases in laboratory and clinical resistance. Clin. Microbiol. Rev., 8(4): 557-584.

32. Singh, R., Saxena, A. and Singh, H. (2009) Identification of group specific motifs in beta-lactamase family of proteins. J. Biomed. Sci., 16(1): 109.

33. Petit, S. (2014) Dictionnaire des Médicaments Vétérinaires. $19^{\text {th }}$ ed. Point Vétérinaire, France. p2558.

34. Sawant, A.A., Hegde, N.V., Straley, B.A., Donaldson, S.C., Love, B.C., Knabel, S.J. and Jayarao, B.M. (2007) Antimicrobial-resistant enteric bacteria from dairy cattle. Appl. Environ. Microbiol., 73(1): 156-163.

35. de Jong, A., Bywater, R., Butty, P., Deroover, E., Godinho, K., Klein, U., Marion, H., Simjee, S., Smets, K., Thomas, V., Vallé, M. and Wheadon, A. (2009) A pan-European survey 
of antimicrobial susceptibility towards human-use antimicrobial drugs among zoonotic and commensal enteric bacteria isolated from healthy food-producing animals. $J$. Antimicrob. Chemother., 63(4): 733-744.

36. Enne, V.I., Cassar, C., Sprigings, K., Woodward, M.J. and Bennett, P.M. (2008) A high prevalence of antimicrobial-resistant Escherichia coli isolated from pigs and a low prevalence of antimicrobial-resistant E. coli from cattle and sheep in Great Britain at slaughter. FEMS Microbiol. Lett., 278(2): 193-199.

37. Desfontis, J.C. (2010) Guide Pratique des Médicaments à Usage Vétérinaire. MED’COM, Paris. p1737.

38. Prescott, J.F., Baggot, J.D. and Walker, R.D. (2000) Antimicrobial Therapy in Veterinary Medicine. $3^{\text {rd }}$ ed. Wiley, Ames, IA. p824.

39. Sayah, R.S., Kaneene, J.B., Johnson, Y. and Miller, R. (2005) Patterns of antimicrobial resistance observed in Escherichia coli isolates obtained from domestic- and wild-animal fecal samples, human septage, and surface water. Appl. Environ. Microbiol., 71(3): 1394-1404.

40. Berghiche, A., Khenenou, T., Bouzebda-AFri, F., Lamraoui, R. and Labied, I. (2017) Detection of the antibiotic residues in broiler chickens by microbiological screening test in Algeria. Glob. Vét., 19(2): 504-508.

41. D’Costa, V.M., King, C.E., Kalan, L., Morar, M., Sung, W.W.L., Schwarz, C., Froese, D., Zazula, G., Calmels, F., Debruyne, R., Golding, G.B., Poinar, H.N. and Wright, G.D. (2011) Antibiotic resistance is ancient. Nature, 477(7365): 457-461.

42. Payne, D.J. and Amyes, S.G. (1991) Transferable resistance to extended-spectrum beta-lactams: A major threat or a minor inconvenience? J. Antimicrob. Chemother., 27(3): 255-261.

43. Lim, S.K., Lee, H.S., Nam, H.M., Cho, Y.S., Kim, J.M., Song, S.W., Park, Y.H. and Jung, S.C. (2007) Antimicrobial resistance observed in Escherichia coli strains isolated from fecal samples of cattle and pigs in Korea during 2003-2004. Int. J. Food Microbiol., 116(2): 283-286.

44. Li, X., Aly, S.S., Su, Z., Pereira, R.V., Williams, D.R., Rossitto, P., Champagne, J.D., Chase, J., Nguyen, T. and Atwill, E.R. (2018) Phenotypic antimicrobial resistance profiles of E. coli and Enterococcus from dairy cattle in different management units on a central California dairy. Clin. Microbiol., 7(2): 1-7.

45. Iabadene, H., Messai, Y., Ammari, H., Ramdani-Bouguessa, N., Lounes, S., Bakour, R. and Arlet, G. (2008) Dissemination of ESBL and qnr determinants in Enterobacter cloacae in Algeria. J. Antimicrob. Chemother., 62(1): 133-136.

46. Yousfi, M., Mairi, A., Touati, A., Hassissene, L., Brasme, L., Guillard, T. and De Champs, C. (2016) Extended-spectrum $\beta$-lactamase and plasmid mediated quinolone resistance in Escherichia coli fecal isolates from healthy companion animals in Algeria. J. Infect. Chemother., 22(7): 431-435.

47. Soufi, L., Abbassi, M.S., Sáenz, Y., Vinué, L., Somalo, S., Zarazaga, M., Abbas, A., Dbaya, R., Khanfir, L., Ben
Hassen, A., Hammami, S. and Torres, C. (2009) Prevalence and diversity of integrons and associated resistance genes in Escherichia coli isolates from poultry meat in Tunisia. Foodborne Pathog. Dis., 6(9): 1067-1073.

48. Rahal, K., Missoum, M.F.K., Bensliman, A., Ammari, H., Abboun, A. and Benamrouche, N. (2015) Surveillance de la Résistance Bactérienne aux Antibiotiques, Rapport D'évaluation, Réseau Algérien de Surveillance de la Résistance des Bactéries aux Antibiotiques, Algérie. p216.

49. Bager, F., Emborg, H.D. and Monnet, D.L. (2001) DANMAP 2000, Report. Consumption of Antimicrobial Agents and Occurrence of Antimicrobial Resistance in Bacteria from Food Animal, Foods and Humans. Danish Zoonosis Center, Denmark.

50. Keyes, K., Hudson, C., Maurer, J.J., Thayer, S., White, D.G. and Lee, M.D. (2000) Detection of florfenicol resistance genes in Escherichia coli isolated from sick chickens. Antimicrob. Agents Chemother., 44(2): 421-424.

51. Chiew, Y.F., Yeo, S.F., Hall, L.M. and Livermore, D.M. (1998) Can susceptibility to an antimicrobial be restored by halting its use? The case of streptomycin versus Enterobacteriaceae. J. Antimicrob. Chemother., 41(2): 247-251.

52. Harada, K., Asai, T., Kojima, A., Ishihara, K. and Takahashi, T. (2006) Role of coresistance in the development of resistance to chloramphenicol in Escherichia coli isolated from sick cattle and pigs. Am. J. Vet. Res., 67(2): 230-235.

53. Kehrenberg, C. and Schwarz, S. (2001) Occurrence and linkage of genes coding for resistance to sulfonamides, streptomycin and chloramphenicol in bacteria of the genera Pasteurella and Mannheimia. FEMS Microbiol. Lett., 205(2): 283-290.

54. Dortet, L., Bonnin, R., Jousset, A., Gauthier, L. and Naas, T. (2016) Émergence de la résistance à la colistine chez les entérobactéries: Une brèche dans le dernier rempart contre la pan-résistance! J. Anti Infect., 18(4): 139-159.

55. AMCRA. (2017) L'OMS Recommande D'arrêter L'utilisation Préventive des Antibiotiques Chez les Animaux. Available from: http://www.amcra.be/fr/nouvelle/ loms-recommande-darrter-lutilisation-prventive-des-antibiotiques-chez-les-animaux/?lid/=14308. Retrieved on 17-04-2019.

56. Sáenz, Y., Briñas, L., Domínguez, E., Ruiz, J., Zarazaga, M., Vila, J. and Torres, C. (2004) Mechanisms of resistance in multiple-antibiotic-resistant Escherichia coli strains of human, animal, and food origins. Antimicrob. Agents Chemother., 48(10): 3996-4001.

57. Rodriguez-Villalobos, H. and Struelens, M.J. (2006) Résistance bactérienne par $\beta$-lactamases à spectre étendu: Implications pour le réanimateur. Réanimation, 15(3): 205-213.

58. AFSSA. (2006) Usages Vétérinaires des Antibiotiques, Résistance Bactérienne et Conséquences Pour la Santé Humaine. Rapport du Groupe de Travail "Antibiorésistance". AFSSA, Maisons-Alfort. p214. 